\title{
MODEL KERENTANAN GERAKAN TANAH WILAYAH KECAMATAN CILILIN MENGGUNAKAN TRIGRS
}

\section{LANDSLIDE SUSCEPTIBILITY MODEL OF CILILIN DISTRICT USING TRIGRS}

\author{
Erizky Ade Kurniawan ${ }^{1}$, Adrin Tohari ${ }^{2}$, Indra Permanajati ${ }^{1}$ \\ ${ }^{1}$ Jurusan Teknik Geologi, Fakultas Teknik, Universitas Jenderal Soedirman, Purwokerto, Jawa Tengah \\ ${ }^{2}$ Pusat Penelitian Geoteknologi, Lembaga Ilmu Pengetahuan Indonesia, Bandung, Jawa Barat
}

\begin{abstract}
ABSTRAK Upaya pengurangan risiko gerakan tanah memerlukan pengetahuan yang baik tentang karakteristik curah hujan yang dapat mempengaruhi kerentanan suatu daerah perbukitan terhadap gerakan tanah. Daerah perbukitan di Kecamatan Cililin di Kabupaten Bandung Barat merupakan salah satu wilayah yang sering mengalami bencana gerakan tanah pada waktu hujan lebat. Makalah ini menyajikan hasil pemodelan kestabilan lereng regional menggunakan Transient Rainfall Infiltration and Grid-based Regional Slope-stability analysis (TRIGRS) untuk mengkaji pengaruh karakteristik curah hujan terhadap tingkat kerentanan gerakan tanah di wilayah Kecamatan Cililin. Hasil pemodelan memperlihatkan lokasi-lokasi gerakan tanah pada umumnya terletak pada zona kerentanan gerakan tanah tinggi. Selain itu, luas zona kerentanan sangat tinggi dapat meningkat dua kali akibat kenaikan intensitas hujan. Pemodelan juga mengindikasikan bahwa zona kerentanan gerakan tanah dikontrol oleh faktor topografi dan geologi. Zona kerentanan gerakan
\end{abstract}

Naskah masuk : 5 Juni 2018

Naskah direvisi : 22 Agustus 2018

Naskah diterima : 10 September 2018

Erizky Ade Kurniawan

Jurusan Teknik Geologi, Fakultas Teknik, Universitas Jenderal Soedirman, Purwokerto, Jawa Tengah

Email : erizkykurniawan005@gmail.com tanah sangat tinggi cenderung terjadi pada wilayah dengan kondisi kemiringan terjal dan tersusun oleh satuan batuan vulkanik berumur Miosen Akhir yang mempunyai nilai kuat geser yang rendah. Sedangkan zona kerentanan rendah terasosiasi dengan wilayah lereng landai yang tersusun oleh satuan tufa batuapung dan batupasir tufan berumur Miosen Tengah yang mempunyai nilai kuat geser yang tinggi.

Kata kunci: curah hujan, gerakan tanah, kerentanan, pemodelan, TRIGRS.

ABSTRACT Efforts to reduce the risk of a landslide require a good knowledge of the characteristics of rainfall on the susceptibility of a hilly area to landslides. The hilly area of Cililin Subdistrict in West Bandung Regency is one of the areas that often experience landslide disasters during heavy rainfalls. This paper presents the regional slope stability modeling using Transient Rainfall Infiltration and Grid-based Regional Slope-stability analysis (TRIGRS) to assess the effect of rainfall on the landslide susceptibility in Cililin Subdistrict. Results of modeling show that the locations of previous landslide incidents are generally located in the very high susceptibility zone. Besides, the areas of very high landslide susceptibility can increase twice due to the increase of rainfall intensity. The modeling also indicates that the landslide susceptibility of the area is mainly controlled by the topographical and geological factors. The high landslide susceptible zone is most likely to occur in the steep hilly areas made up of soils with low shear strength values which were originated from the Upper Miocene volcanic rocks. Whereas very gentle slope areas are made up of high shear strength soil originated from the Middle Miocene (pumice tuff and 
tuffaceous sandstone) that belongs to the low landslide susceptibility zone.

Keywords: landslide, modelling, rainfall, susceptibility, TRIGRS.

\section{PENDAHULUAN}

Jawa Barat merupakan salah satu provinsi di Indonesia yang sering mengalami bencana gerakan tanah selama periode musim hujan. Kondisi geologi dan kemiringan lereng menyebabkan daerah perbukitan menjadi rentan terhadap gerakan tanah. Tidak jarang, peristiwa gerakan tanah juga menimbulkan korban jiwa dan kerugian harta benda. Menurut data kejadian bencana gerakan tanah di Indonesia selama 9 tahun terakhir (BNPB, 2018), sebanyak 991 kejadian bencana gerakan tanah terjadi di wilayah Provinsi Jawa Barat, yang mana sebanyak 65 peristiwa terjadi di wilayah Kabupaten Bandung Barat. Kecamatan Cililin merupakan salah satu wilayah yang sangat rentan gerakan tanah. Berdasarkan peta kerentanan gerakan tanah (PVMBG, 2011), wilayah Kecamatan Cililin berada pada zona kerentanan gerakan tanah menengah hingga tinggi, luas daerah rawan bencana tanah longsor di wilayah Kecamatan Cililin mencapai 1.153,23 Ha. Dalam kurun waktu 2010-2018, telah tercatat sebanyak 11 kejadian bencana gerakan tanah di wilayah ini. Untuk itu, upaya-upaya pengurangan risiko bencana perlu dilakukan dengan melakukan mitigasi dan kesiapsiagaan terhadap ancaman gerakan tanah untuk mengurangi risiko bencana.

Prediksi ancaman gerakan tanah merupakan salah satu upaya kesiapsiagaan terhadap gerakan tanah. Prediksi ancaman gerakan tanah harus berdasarkan informasi yang tepat, dalam hal waktu dan lokasi gerakan tanah yang akan terjadi. Berbagai macam metode pemodelan prediktif gerakan tanah cenderung menggunakan pendekatan deterministik. Pendekatan tersebut menggunakan persamaan matematika untuk menjelaskan proses lereng dengan mempertimbangkan pengaruh parameter topografi, geoteknik dan hidrologis pada inisiasi gerakan tanah. Sebagai contoh, Stability Index MAPping atau SINMAP (Pack et al., 1998, 2001) menggunakan pendekatan deterministik untuk menghitung risiko gerakan tanah translasi dangkal dengan mempertimbangkan neraca air di dalam lereng. Shallow Slope Stability Model atau SHALSTAB (Dietrich et al., 1993, 1995;
Montgomery dan Dietrich, 1994; Montgomery et al., 1998) menggunakan model limpasan kondisi tetap (steady-state runoff) dan kestabilan lereng menerus, untuk memetakan potensi gerakan tanah dangkal.

Transient Rainfall Infiltration and Grid-based Regional Slope Stability atau TRIGRS (Baum et al., 2002) ditulis dalam kode Fortran berdasarkan solusi linear dari persamaan Richards yang dikembangkan oleh Iverson (2000). TRIGRS memodelkan efek curah hujan transien pada kestabilan lereng pada wilayah yang luas. Model TRIGRS telah berhasil digunakan untuk mengevaluasi gerakan tanah akibat curah hujan secara kuantitatif di banyak negara. Beberapa contoh termasuk Washington, USA (Godt et al., 2008); Mt. Tenliao, Taipei, Taiwan (Chen et al., 2005); and Mt. Gyemyeong, Yangju, South Korea (Kim et al., 2010). Beberapa peneliti seperti Salciarini et al. (2006) dan Vieira et al. (2010) membuktikan kehandalan TRIGRS untuk memprediksi gerakan tanah dangkal dengan menggunakan parameter tanah yang terlebih dahulu diperkirakan berdasarkan pengukuran lapangan yang terbatas.

Model TRIGRS telah juga digunakan untuk memetakan kerentanan gerakan tanah di Indonesia. Tohari et al. (2005) melakukan penelitian pemodelan prediktif bahaya gerakan tanah tipe luncuran berbasis infiltrasi air hujan transien pada daerah ruas jalan Cadas Pangeran di Kabupaten Sumedang dan di daerah perbukitan Mandalawangi di Kabupaten Garut. Penelitian dilakukan menggunakan metode yang sama dengan tujuan untuk mengetahui penyebab terjadinya gerakan tanah tipe luncuran di daerah hollow dan side slope di kedua lokasi tersebut. Hasil pemodelan mengindikasikan bahwa faktor karakter curah hujan, dengan intensitas dan durasi lamanya, sebagai pengontrol waktu dan lokasi terjadinya gerakan tanah. Selain itu, kemiringan lereng dan bentuk lereng juga merupakan faktor pengontrol distribusi dari gerakan tanah tipe luncuran yang sesuai dengan bukti yang dapat dlihat di kedua lokasi tersebut.

Sarah et al. (2015) menyajikan hasil pemodelan kerentanan lereng yang menunjukkan kesesuaian antara zona kerentanan gerakan tanah dan lokasi bencana gerakan tanah di daerah Tawamangu, Jawa Tengah. Sedangkan Sugianti et al. (2016) menggunakan aplikasi TRIGRS untuk pemetaan 


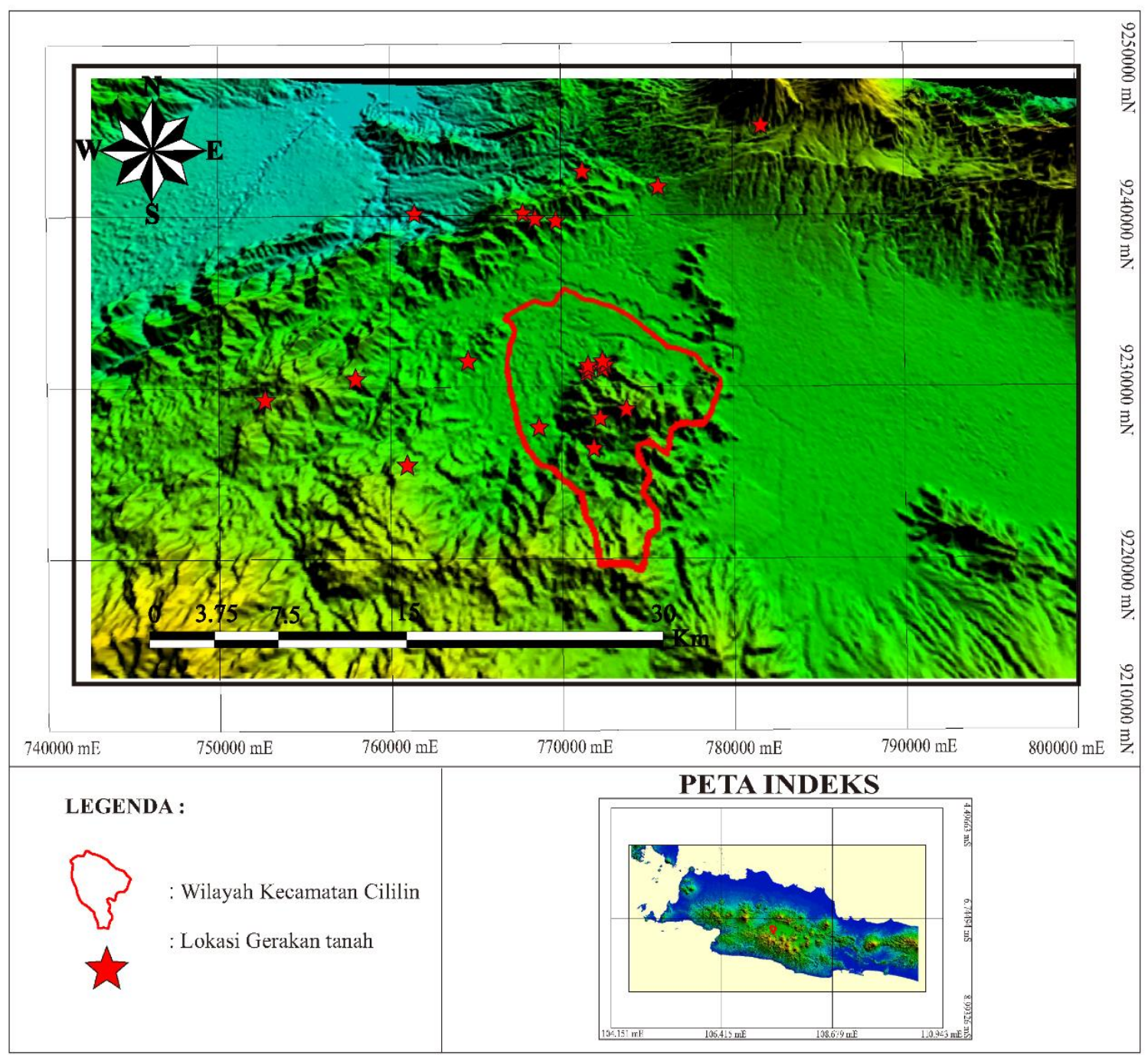

Gambar 1. Peta lokasi penelitian di Kecamatan Cililin, Kabupaten Bandung Barat.

kerentanan gerakan tanah di wilayah Kabupaten Sukabumi, Jawa Barat. Hasil pemodelan mengindikasikan bahwa hampir semua peristiwa gerakan tanah di wilayah Kabupaten Sukabumi terjadi pada zona kerentanan menengah hingga tinggi. Dan peningkatan luasan zona kerentanan gerakan tanah tinggi juga dapat terjadi pada saat mendekati akhir periode bulan basah, meskipun jumlah hujan harian semakin berkurang di wilayah ini.

Makalah ini menyajikan hasil pemodelan kerentanan gerakan tanah menggunakan TRIGRS, di wilayah Kecamatan Cililian, Kabupaten Bandung Barat, dengan mempertimbangkan variasi kemiringan lereng dan karakteristik keteknikan lapisan tanah dan variasi curah hujan. Adapun sasaran dari pemodelan ini adalah untuk (1) mengetahui faktor-faktor yang mempengaruhi tingkat kerentanan gerakan tanah di daerah penelitian dari hasil pemodelan dengan TRIGRS, dan (2) mengkaji aspek risiko wilayah pemukiman pada zona kerentanan gerakan tanah sangat tinggi.

\section{LOKASI PENELITIAN}

Gambar 1 menyajikan lokasi penelitian yang terletak di Kecamatan Cililin, Kabupaten Bandung Barat, Provinsi Jawa Barat terletak pada koordinat $109^{\circ} 41^{\prime} 22,2^{\prime \prime}-109^{\circ} 42^{\prime} 45,6^{\prime \prime}$ 'BT dan 7¹7'43,2"'$7^{\circ} 03^{\prime} 01,9^{\prime}$ 'LS dan memiliki kemiringan lereng yang datar sampai terjal pada ketinggian antara $650 \mathrm{~m}$ dan $1400 \mathrm{~m}$ di atas permukaan laut.

Daerah studi didominasi oleh perbukitan dengan kemiringan landai sampai sangat terjal. Pada bagian selatan - timur daerah studi, terdapat perbukitan yang curam hingga sangat terjal. Sedangkan perbukitan landai hingga curam 
mendominasi daerah bagian utara - barat. Elevasi terendah dan tertinggi masing-masing yaitu $650 \mathrm{~m}$ dan $1400 \mathrm{~m}$ diatas permukaan laut. Pola aliran yang berkembang yaitu radial dan subdendritik.

Berdasarkan peta geologi regional Lembar Bandung (Silitonga, 1973), Lembar Cianjur (Sudjatmiko, 1972) dan Sindangbarang dan Lembar Bandarwaru (Koesmono et al., 1996), lokasi studi terdiri dari beberapa satuan batuan, dari yang tertua hingga termuda, sebagai berikut (Gambar 2):

- Satuan breksi tufan berbatuapung, batupasir tufaan, napal tufan (Mt), berumur Miosen Tengah (Sudjatmiko, 1972).

- Satuan breksi andesit, basal, lava, batupasir tufaan dan konglomerat $(\mathrm{Pb})$, dengan umur relatif Miosen Akhir (Silitonga, 1973).

- Satuan batuan andesit (A atau Pa) berumur relatif Pliosen (Sudjatmiko, 1972; Koesmono et al., 1996).
- Satuan endapan danau (Q1) berumur Holosen, yang tersusun atas lempung tufaan, batupasir tufaan, kerikil tufaan, dan terkadang mengandung sisipan breksi (Soedjatmiko, 1972; Silitonga, 1973).

- Satuan aluvium (Qa), tersusun atas lempung, lanau, pasir, kerikil, berumur Holosen (Sudjatmijo, 1972; Silitonga,1973).

Berdasarkan Gambar 2, lokasi gerakan tanah banyak terjadi pada daerah perbukitan yang tersusun oleh satuan breksi andesit $(\mathrm{Pb})$. Dengan demikian lapisan batuan ini rentan terhadap gerakan tanah.

\section{METODE}

\section{Parameter Pemodelan TRIGRS}

Beberapa parameter diperlukan untuk pemodelan pengaruh infiltrasi air hujan terhadap kestabilan lereng menggunakan TRIGRS, yaitu faktor topografi seperti ketinggian dan kemiringan, ketebalan tanah, sifat keteknikan dan parameter

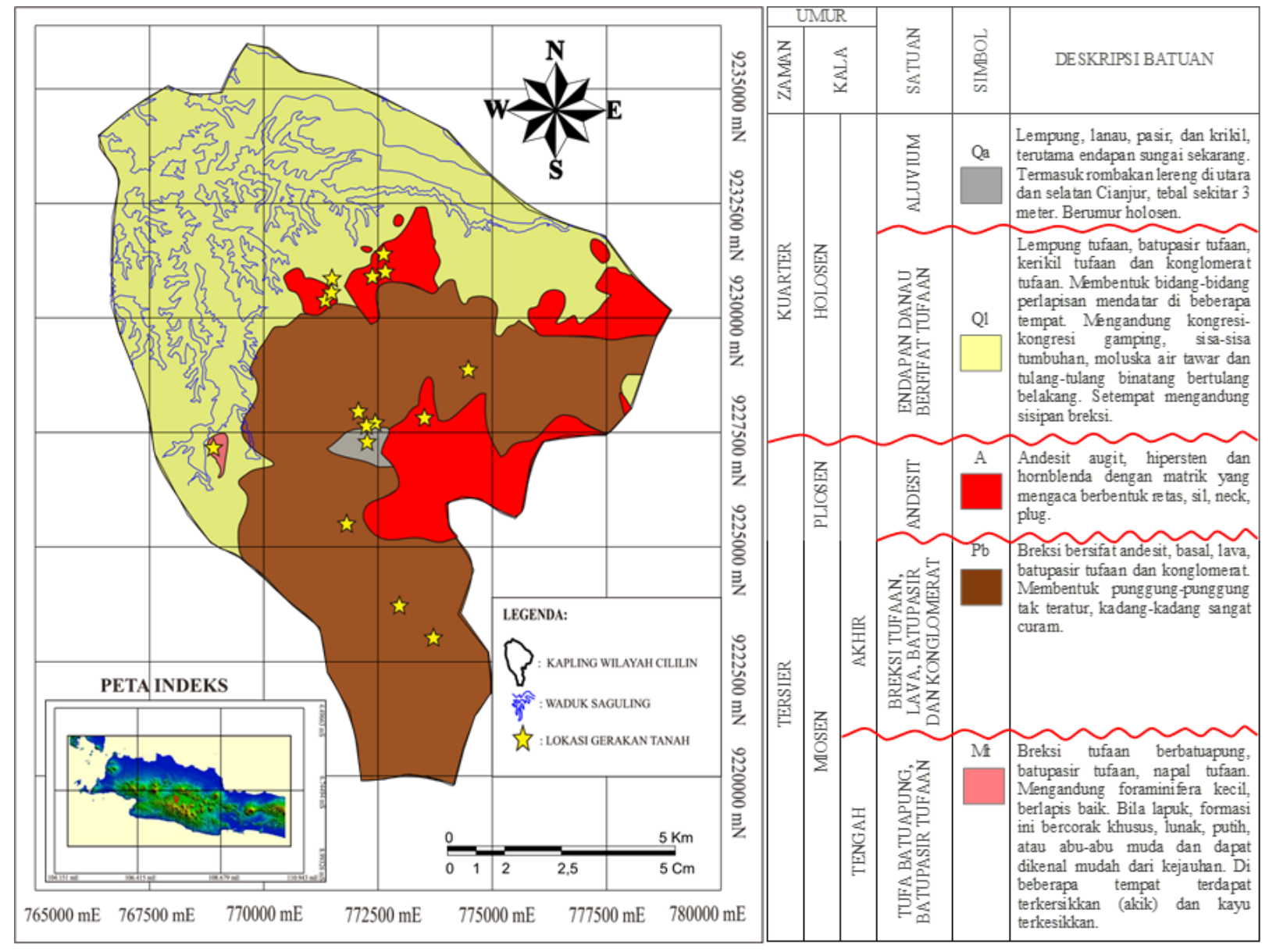

Gambar 2. Peta geologi Kecamatan Cililin, Kabupaten Bandung Barat. 


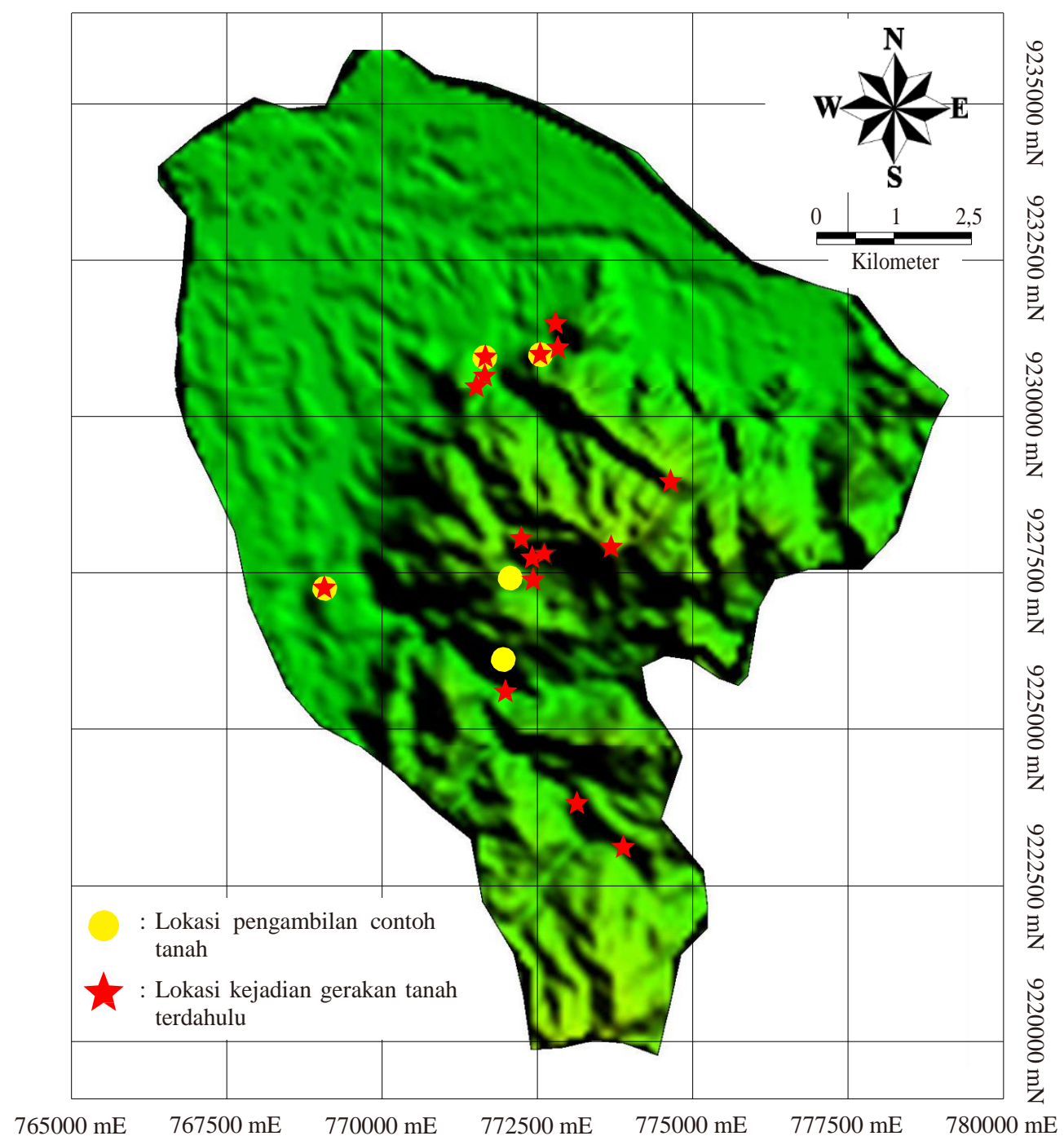

Gambar 3. Peta lokasi pengamatan gerakan tanah dan pengambilan contoh-contoh tanah.

hidrologis tanah serta parameter curah hujan. Analisis topografi untuk aspek ketinggian dan kemiringan lereng di wilayah Kecamatan Cililin, dilakukan dengan menggunakan citra SRTM (Shuttle Radar Topography Mission) dengan resolusi spasial $90 \mathrm{~m}$. Aplikasi ArcGIS 9.1 digunakan untuk menciptakan grid dengan sel berukuran $25 \mathrm{~m} \times 25 \mathrm{~m}$, dan untuk mengkuantifikasi informasi di atas untuk setiap sel dari model elevasi digital.

Untuk mendapatkan parameter sifat mekanika tanah yang digunakan dalam pemodelan TRIGRS, beberapa conto tanah tak terganggu yang mewakili setiap jenis litologi didapatkan dengan menggunakan tabung sampel. Lokasi pengambilan contoh-contoh tanah disajikan pada Gambar 3. Uji karakterisasi mekanika tanah di laboratorium dilakukan pada setiap contoh tanah untuk mendapatkan parameter fisik, keteknikan dan hidrologis tanah sebagai berikut:

- Berat isi tanah $\left(\gamma_{w}\right)$ yang berdasarkan standar ASTM D 297-76.

- Kohesi efektif $\left(c^{\prime}\right)$ dan sudut geser efektif $\left(\varphi^{\prime}\right)$ yang berdasarkan uji triaksial kondisi termampatkan-tak teralirkan (CU) dengan mengacu pada ASTM D4767M.

- Koefisien permeabilitas jenuh $\left(K_{s}\right)$ yang diperoleh dari hasil uji falling head permeameter dengan mengacu pada ASTM D585.

Parameter hidrolik tanah yaitu nilai laju infiltrasi kondisi steady $\left(I_{z}\right)$ diperoleh dari hasil uji infiltrasi dengan metode double ring infiltrometer, yang 
dilakukan di setiap lokasi pengambilan contoh tanah. Sementara itu, nilai difusivitas tanah $\left(D_{0}\right)$ mempunyai hubungan dengan nilai koefisien permeabilitas jenuh $\left(K_{s}\right)$. Untuk analisis ini, nilai $D_{0}$ diasumsikan sebesar 200 kali nilai $K_{s}$.

Nilai dan satuan dari parameter-parameter keteknikan dan hidrologis tanah disajikan pada Tabel 1. Nilai parameter fisik, keteknikan dan hidrolik tanah bervariasi berdasarkan jenis litologi, sehingga akan mempengaruhi kerentanan lereng di wilayah Kecamatan Cililin.

Tabel 1. Ringkasan nilai parameter sifat mekanika tanah untuk setiap formasi batuan yang digunakan dalam pemodelan TRIGRS.

\begin{tabular}{cccccc}
\hline $\begin{array}{c}\text { Parameter } \\
\text { tanah }\end{array}$ & Q1 & A & Mt & $\mathrm{Pb}$ & $\mathrm{Qa}$ \\
\hline$\gamma_{s}\left(\mathrm{kN} / \mathrm{m}^{3}\right)$ & 17,9 & 17,3 & 16,6 & 16,5 & 16,4 \\
$c^{\prime}(\mathrm{kPa})$ & 6,4 & 1,3 & 18,2 & 9,0 & 2,1 \\
$\varphi^{\prime}\left({ }^{\circ}\right)$ & 15,0 & 36,7 & 10,2 & 29,5 & 27,8 \\
$\mathrm{~K}_{\mathrm{s}}\left(\mathrm{x} \mathrm{10} 0^{-9}\right.$ & 238 & 10,2 & 332 & 316 & 21,4 \\
$\mathrm{~m} /$ detik $)$ & & & & & \\
$\begin{array}{c}\mathrm{I}_{\mathrm{z}}\left(\mathrm{x} \mathrm{10} 0^{-6}\right. \\
\mathrm{m} / \text { detik) }\end{array}$ & 8,08 & 222 & 5,05 & 116 & 0,41 \\
\hline
\end{tabular}

\section{Pemodelan Infiltrasi Airhujan Terhadap Kestabilan Lereng}

Untuk menghasilkan model spasial pengaruh air hujan terhadap kestabilan lereng di lokasi penelitian, tahap-tahap pemodelan menggunakan TRIGRS adalah sebagai berikut:

Tahap 1: analisis data topografi berupa data ketinggian dan arah lereng dengan menggunakan program TopoIndex (Baum et al., 2002), untuk menghasilkan perhitungan rute aliran permukaan yang digunakan dalam pemodelan kestabilan lereng.

Tahap 2: analisis kestabilan lereng menggunakan TRIGRS (Baum et al., 2002) yang berdasarkan metode analisis kestabilan lereng menerus. Persamaan untuk menghitung nilai faktor keamanan lereng (FK), dengan memperhatikan infiltrasi air hujan, untuk model lereng menerus adalah sebagai berikut :

$$
F K=\frac{\tan \varphi^{\prime}}{\tan \theta}+\frac{c^{\prime}-\psi(Z, t) \gamma_{w} \tan \varphi^{\prime}}{\gamma_{s} Z \sin \theta \cos \theta}
$$

dimana, $\gamma_{w}$ adalah berat isi air, $t$ adalah waktu, Z adalah ketebalan lapisan tanah (m), $\psi$ adalah tekanan airpori transien $(\mathrm{Pa}), \gamma_{s}$ adalah berat isi tanah $\left(\mathrm{kN} / \mathrm{m}^{3}\right), c^{\prime}$ adalah kohesi efektif $(\mathrm{kPa}), \varphi^{\prime}$ adalah sudut geser efektif $\left({ }^{\circ}\right)$, and $\theta$ adalah sudut kemiringan bidang gelincir $\left(^{\circ}\right)$. Nilai $F K<1$ menunjukkan kondisi lereng tidak stabil. Untuk memodelkan infiltrasi air hujan ke dalam lereng, TRIGRS (Baum et al., 2002) menggunakan solusi analitik dari persamaan differensial yang merepresentasikan aliran vertikal 1 dimensi di dalam material homogen dan isotropik untuk kondisi jenuh dan tidak jenuh air. Pemodelan infiltrasi air hujan berdasarkan pada solusi linear Iverson (2000) dan ekstensi dari persamaan Richard oleh Baum et al. (2002). Solusi untuk tekanan air pori transien dihitung dengan menggunakan persamaan berikut ini :

$$
\begin{aligned}
& \psi(Z, t) \\
& =[Z-d] \beta \\
& +2 \sum_{n=1}^{N} \frac{I_{n Z}}{K_{s}} H(t \\
& \left.-t_{n}\right)[D(t \\
& \left.\left.-t_{n}\right)\right]^{\frac{1}{2}} \sum_{m=1}^{\infty}\left\{\operatorname{ierfc}\left[\frac{(2 m-1) d_{L Z}-\left(d_{L Z}-Z\right)}{2\left[D_{1}\left(t-t_{n}\right)\right]^{\frac{1}{2}}}\right]\right. \\
& \left.+\operatorname{ierfc}\left[\frac{(2 m-1) d_{L Z}-\left(d_{L Z}-Z\right)}{2\left[D_{1}\left(t-t_{n}\right)\right]^{\frac{1}{2}}}\right]\right\} \\
& -2 \sum_{n=1}^{N} \frac{I_{n Z}}{K_{S}} H(t \\
& \left.-t_{n}\right)[D(t \\
& \left.\left.-t_{n}\right)\right]^{\frac{1}{2}} \sum_{m=1}^{\infty}\left\{i \operatorname{ierfc}\left[\frac{(2 m-1) d_{L Z}-\left(d_{L Z}-Z\right)}{2\left[D_{1}\left(t-t_{n}\right)\right]^{\frac{1}{2}}}\right]\right. \\
& \left.+\operatorname{ierfc}\left[\frac{(2 m-1) d_{L Z}-\left(d_{L Z}-Z\right)}{2\left[D_{1}\left(t-t_{n}\right)\right]^{\frac{1}{2}}}\right]\right\}
\end{aligned}
$$

dimana, $\psi$ adalah tekanan airtanah; $Z=z / \cos \delta, \mathrm{Z}$ adalah kedalaman dibawah permukaan tanah dalam arah vertikal $(\mathrm{m}) ; z$ adalah arah koordinat normal terhadap lereng, dan $\delta$ adalah sudut lereng $\left(^{\circ}\right) ; d$ adalah kedalaman muka airtanah kondisi steady yang diukur dalam arah vertikal $(\mathrm{m}) ; d_{L Z}$ adalah kedalaman batas impermeabel diukur arah vertikal $(\mathrm{m}) ; \quad \beta=\cos ^{2} \delta-(I Z L T / K S) ; \quad K S$ adalah koefisien permeabilitas jenuh untuk arah $Z$ (m/detik); IZLT adalah fluks permukaan kondisi steady $(\mathrm{m}) ; I_{n Z}$ adalah fluks permukaan pada 
intensitas tertentu untuk interval ke-n; $D_{l}$ $=D_{0} / \cos ^{2} \delta$, dimana $D_{0}$ adalah diffusivitas hidrolik kondisi jenuh $\left(D_{0}=K_{S} / S_{S}\right.$, dimana $K_{S}$ adalah koefisien permeabilitas jenuh dan $S_{S}$ adalah specific storage), $N$ adalah jumlah total interval waktu; $H\left(t-t_{n}\right)$ adalah Heaviside step function dan $t_{n}$ adalah waktu pada interval waktu ke-n dalam urutan infiltrasi airhujan.

Untuk memperlihatkan pengaruh kenaikan intensitas hujan pada kestabilan lereng di lokasi penelitian, pemodelan TRIGRS menggunakan curah hujan dengan durasi 3 hari dengan intensitas untuk hari ke-1 (ri0) sebesar $1,16 \times 10^{-8} \mathrm{~m} /$ detik (atau $1 \mathrm{~mm} /$ hari), pada hari ke-2 (ri1) sebesar $1,16 \times 10^{-7} \mathrm{~m} /$ detik (atau $10 \mathrm{~mm} / \mathrm{hari}$ ) dan pada hari ke-3 (ri2) sebesar $2,89 \times 10^{-7} \mathrm{~m} /$ detik (atau 25 $\mathrm{mm} /$ hari).

\section{Zonasi Kerentanan Gerakan Tanah}

Tabel 2 menyajikan zonasi kerentanan gerakan tanah berdasarkan nilai faktor keamanan (FK) lereng yang merupakan modifikasi dari Ward (1976). Nilai faktor keamanan (FK) kurang dari 1 dijadikan batas untuk zonasi kerentanan sangat tinggi. Sedangkan nilai FK > 2,0 untuk zonasi kerentanan sangat rendah.

Tabel 2. Zonasi kerentanan gerakan tanah berdasarkan nilai faktor keamanan lereng (modifikasi dari Ward, 1976).

\begin{tabular}{ll}
\hline $\begin{array}{c}\text { Faktor keamanan } \\
(\mathrm{FK})\end{array}$ & \multicolumn{1}{c}{ Kerentanan gerakan tanah } \\
\hline $\mathrm{FK}>2,0$ & Kerentanan sangat rendah \\
$1,7<\mathrm{FK}<2,0$ & Kerentanan rendah \\
$1,2<\mathrm{FK}<1,7$ & Kerentanan menengah \\
$1,0<\mathrm{FK}<1,2$ & Kerentanan tinggi \\
$\mathrm{FK}<1,0$ & Kerentanan sangat tinggi \\
\hline
\end{tabular}

\section{HASIL DAN PEMBAHASAN}

\section{Pengaruh Curah Hujan Terhadap Perubahan Kerentanan Gerakan Tanah}

Gambar 4 hingga 6 menyajikan hasil pemodelan TRIGRS berupa peta zonasi kerentanan gerakan tanah di wilayah Kecamatan Cililin. Sebagaimana dapat dilihat pada Gambar 4, daerah perbukitan di
Kecamatan Cililin umumnya didominasi oleh zona kerentanan gerakan tanah menengah. Pada kondisi curah hujan ri0, zona kerentanan gerakan tanah tinggi hingga sangat tinggi terbentuk pada sebagian kecil daerah perbukitan. Pada kondisi ini, kerentanan gerakan tanah dikontrol oleh parameter keteknikan tanah dan kemiringan lereng.

Dengan kenaikan intensitas hujan menjadi ri1, zona kerentanan sangat tinggi menjadi bertambah banyak dibandingkan pada kondisi ri0 (Gambar 5). Hal ini disebabkan oleh pembentukan tekanan airpori transient yang menyebabkan kestabilan lereng terganggu sehingga menghasilkan pertumbuhan zona kerentanan sangat tinggi terutama pada daerah-daerah lereng yang berada pada zona kerentanan tinggi. Akan tetapi, peningkatan intensitas hujan sebesar ri2 tidak menyebabkan penambahan zona kerentanan sangat tinggi (Gambar 6). Dengan kata lain, infiltrasi air hujan tidak dapat menurunkan kestabilan lereng perbukitan pada zona kerentanan sangat rendah hingga menengah.

Gambar 7 menyajikan perubahan luas daerah rentan gerakan tanah (dalam \%). Berdasarkan histogram ini, daerah lereng yang berada dalam zona kerentanan sangat tinggi $(\mathrm{FK}<1,0)$ memiliki persentase terkecil pada saat kondisi ri0. Luas daerah dalam zona kerentanan gerakan tanah sangat tinggi meningkat dua kali lipat akibat curah hujan dengan intensitas ri1. Kenaikan luas daerah rentaan gerakan tanah juga terjadi pada zona kerentanan tinggi. Dengan demikian, pengaruh infiltrasi air hujan menjadi faktor penyebab penambahan luas daerah kerentanan tinggi dan sangat tinggi. Kenaikan luas daerah rentan tinggi dan sangat tinggi terasosiasi dengan penurunan luas daerah rentan sangat rendah hingga menengah.

Perubahan intensitas hujan menjadi ri2 tidak menyebabkan penambahan luas daerah rentan tinggi dan sangat tinggi secara signifikan. Hal ini mengindikasikan bahwa curah hujan dengan intensitas ri2 tidak dapat menghasilkan tekanan air-pori transien yang diperlukan untuk memperkecil pengaruh kuat geser tanah pada nilai faktor keamanan lereng perbukitan pada zona kerentanan menengah. Dengan demikian curah hujan dengan durasi yang lama diperlukan untuk menyebabkan ketidakstabilan lereng pada zona kerentanan menengah. 


\section{Zonasi Kerentanan Gerakan Tanah}

Hasil pemodelan menunjukkan bahwa wilayah Kecamatan Cililin dapat dibagi menjadi 5 zona kerentanan gerakan tanah berdasarkan pada nilai faktor keamanannya dan kondisi geologi dan morfologi lereng, sebagai berikut:

\section{Zona Kerentanan Gerakan Tanah Sangat Rendah}

Zona ini memiliki nilai faktor keamanan (FK) lebih dari 2,0 dan terdapat lebih dominan pada daerah lereng dengan kemiringan $0^{\circ}-8^{\circ}$, yang termasuk klasifikasi lereng datar hingga landai. Zona kerentanan ini lebih banyak terjadi pada satuan geomorfologi dataran danau dan satuan dataran fluvial-alluvial, dan luas persebaran pada daerah yang didominasi oleh satuan aluvium, (Qa), endapan danau (Ql) dan breksi tufan berbatuapung, batupasir tufaan, batupasir tufaan, napal tufan (Mt). Potensi terjadinya gerakan tanah dizona ini relatif sangat sulit terjadi, karena kondisi kemiringan lereng relatif datar. Ketidakstabilan lereng akan lebih dipengaruhi oleh faktor aktifitas manusia seperti penggalian.

\section{Zona Kerentanan Gerakan Tanah Rendah}

Zona ini memiliki nilai faktor keamanan berkisar antara 1,7 dan 2,0. Lebih dominan berada pada daerah dengan kemiringan lereng mulai dari $4^{\circ}$

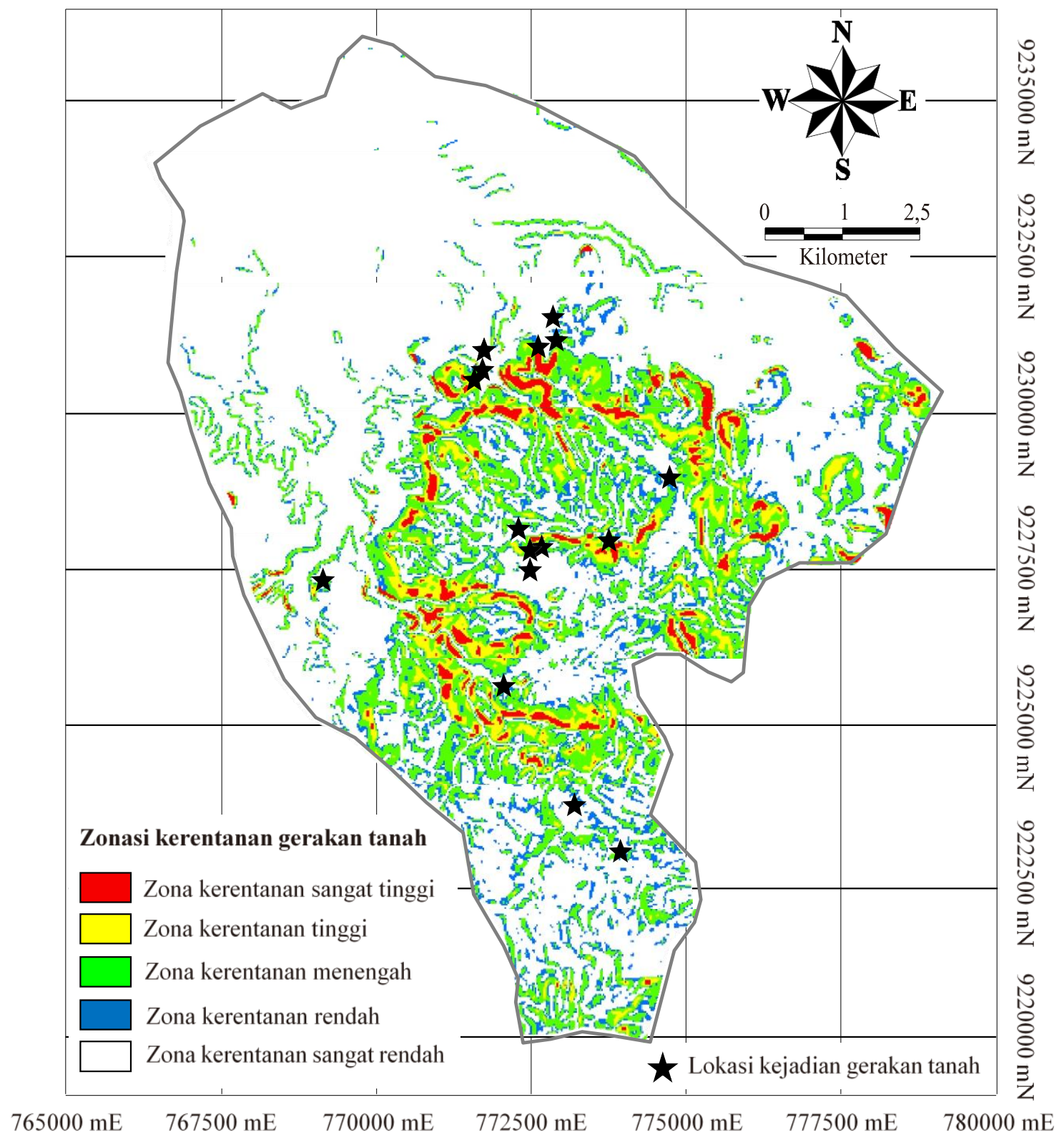

Gambar 4. Zonasi kerentanan gerakan tanah wilayah Kecamatan Cililin akibat intensitas hujan ri0. 


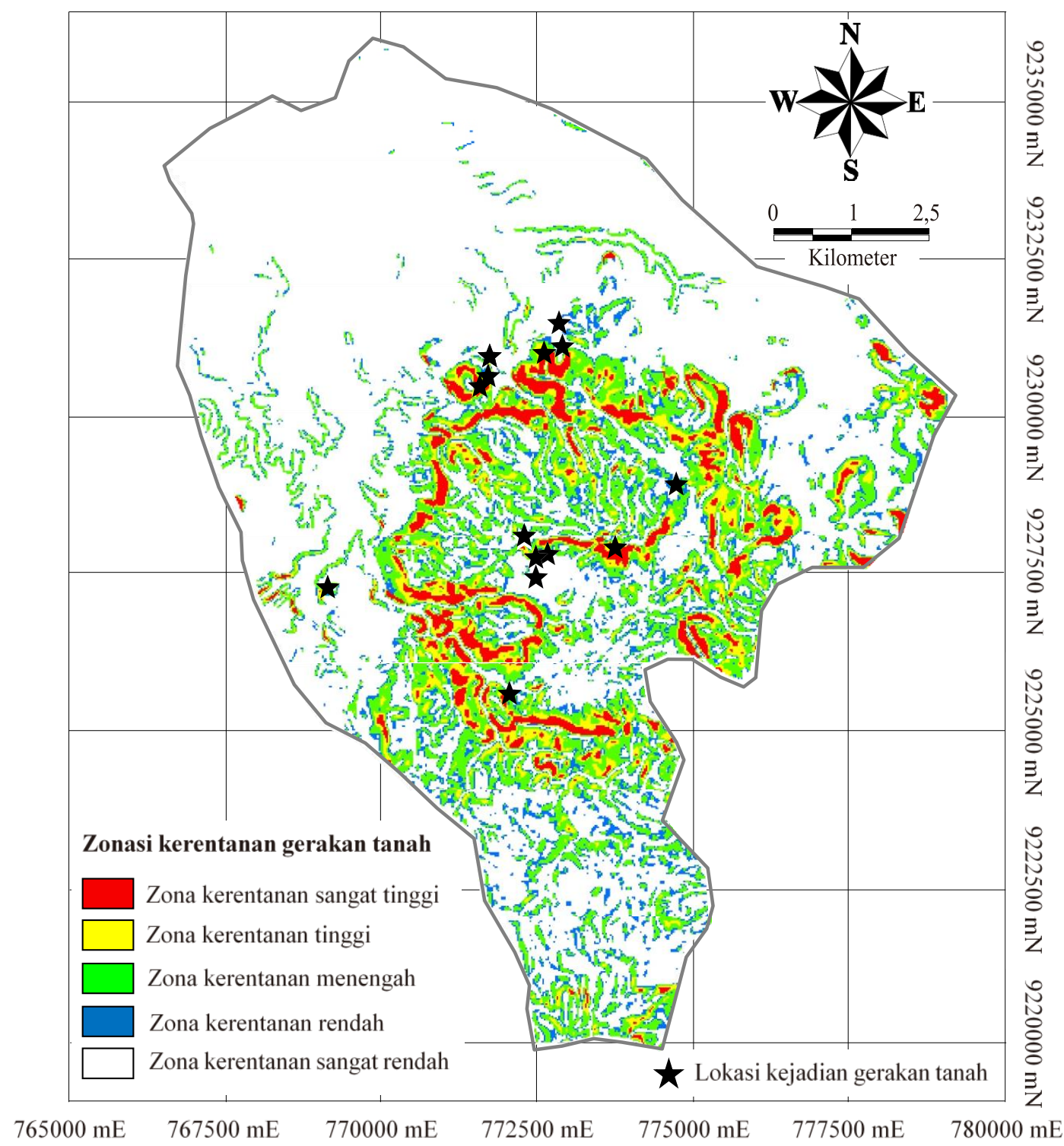

Gambar 5. Zonasi kerentanan gerakan tanah wilayah Kecamatan Cililin akibat intensitas hujan ri1.

hingga $8^{\circ}$, yang termasuk kedalam klasifikasi lereng landai hingga agak curam. Zona kerentanan ini lebih dominan dijumpai pada satuan pegunungan denudasional, yang tersusun oleh satuan batuan breksi andesit $(\mathrm{Pb})$. Potensi terjadinya gerakan tanah di zona ini masih relatif sulit terjadi, karena kondisi kemiringan lereng relatif datar sehingga lereng akan mengalami ketidakstabilan akibat faktor aktifitas manusia (penggalian) dan tataguna lahan yang kurang tepat.

\section{Zona Kerentanan Gerakan Tanah Menengah}

Zona ini memiliki nilai faktor keamanan berkisar antara 1,2 dan 1,7. Berada pada daerah dengan kemiringan lereng mulai dari $8^{\circ}$ hingga $16^{\circ}$, zona ini termasuk kedalam klasifikasi lereng curam hingga terjal. Zona ini lebih banyak dijumpai pada satuan pegunungan denudasional dan satuan pegunungan vulkanik dan umumnya terjadi lebih dominan pada satuan batuan breksi andesit $(\mathrm{Pb})$ dan andesit (A). Gerakan tanah di zona ini dapat terjadi jika dipicu oleh curah hujan lebat dengan durasi lama.

\section{Zona Kerentanan Gerakan Tanah Tinggi}

Zona ini memiliki nilai faktor keamanan berkisar antara 1,2 dan 1,0. Berada pada kemiringan lereng mulai dari $16^{\circ}$ hingga $35^{\circ}$, zona ini termasuk kedalam lereng curam hingga terjal. Oleh sebab 


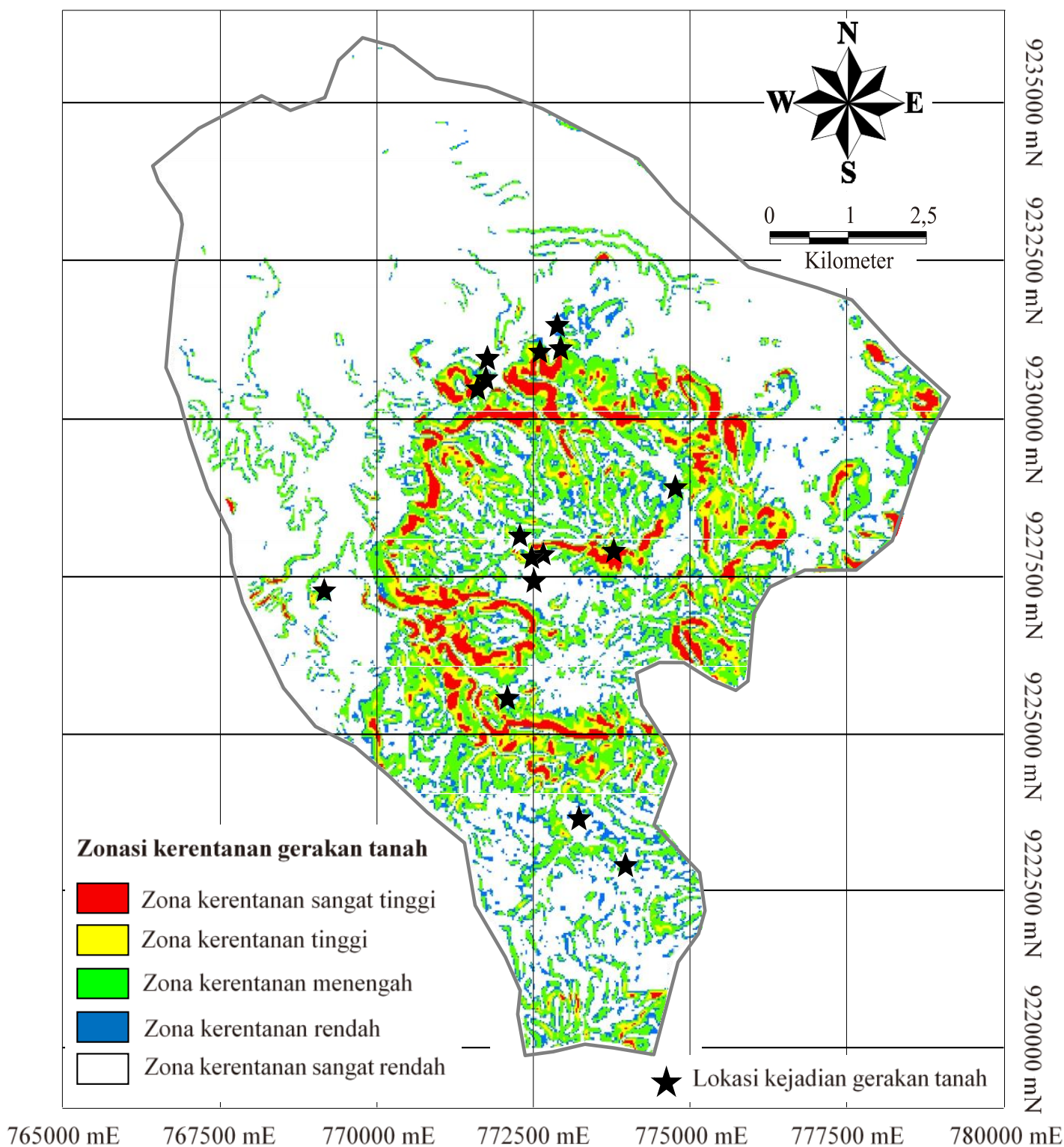

Gambar 6. Zonasi kerentanan gerakan tanah wilayah Kecamatan Cililin akibat intensitas hujan ri2.

itu, kemiringan lereng menjadi faktor penting dalam persebarannya. Zona ini lebih banyak pada satuan pegunungan denudasional dan satuan pegunungan vulkanik, dan pada umumnya terjadi relatif lebih dominan pada satuan breksi andesit $(\mathrm{Pb})$. Gerakan tanah dapat terjadi di zona ini, termasuk daerah bekas gerakan tanah lama, akibat curah hujan dengan durasi lama.

\section{Zona Kerentanan Gerakan Tanah Sangat Tinggi}

Zona ini memiliki nilai faktor keamanan kurang dari 1,0 dan lebih banyak terjadi di daerah dengan kemiringan lereng mulai dari $35^{\circ}$ hingga $55^{\circ}$, yang termasuk kedalam klasifikasi lereng terjal. Zona ini lebih banyak dijumpai pada satuan pegunungan denudasional dan satuan pegunungan vulkanik, dan pada umumnya terbentuk lebih luas pada satuan breksi andesit $(\mathrm{Pb})$ dan batuan andesit $(\mathrm{A})$. Gerakan tanah berukuran besar sampai sangat kecil banyak terjadi di zona ini akibat curah hujan dengan intensitas cukup tinggi. Gerakan tanah lama dapat aktif bergerak kembali akibat curah hujan dengan durasi lama.

\section{Kajian Zona Risiko Bencana Berdasarkan Pemodelan TRIGRS}

Hasil pemodelan TRIGRS dapat digunakan untuk mengkaji potensi bencana gerakan tanah di suatu 


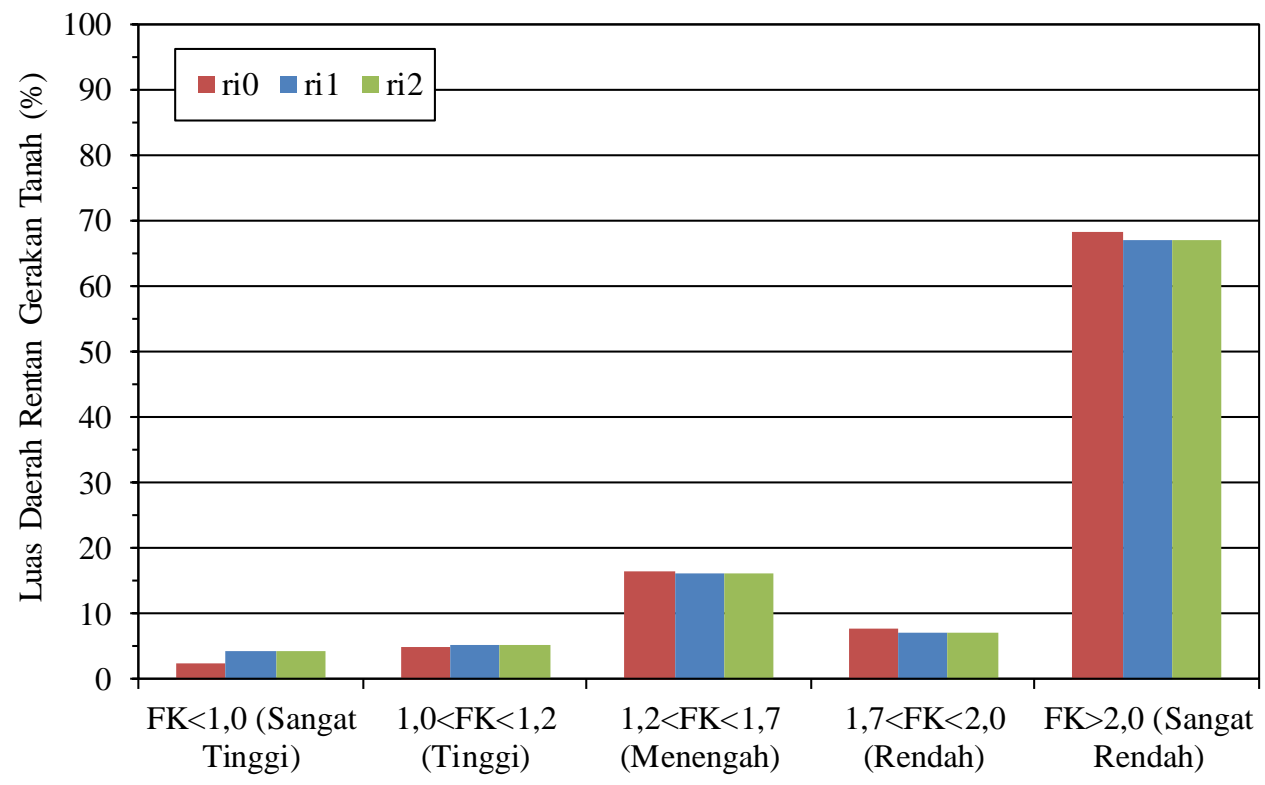

Faktor Keamanan (FK)

Gambar 7. Perubahan luas daerah rentan gerakan tanah akibat kenaikan intensitas curah hujan.

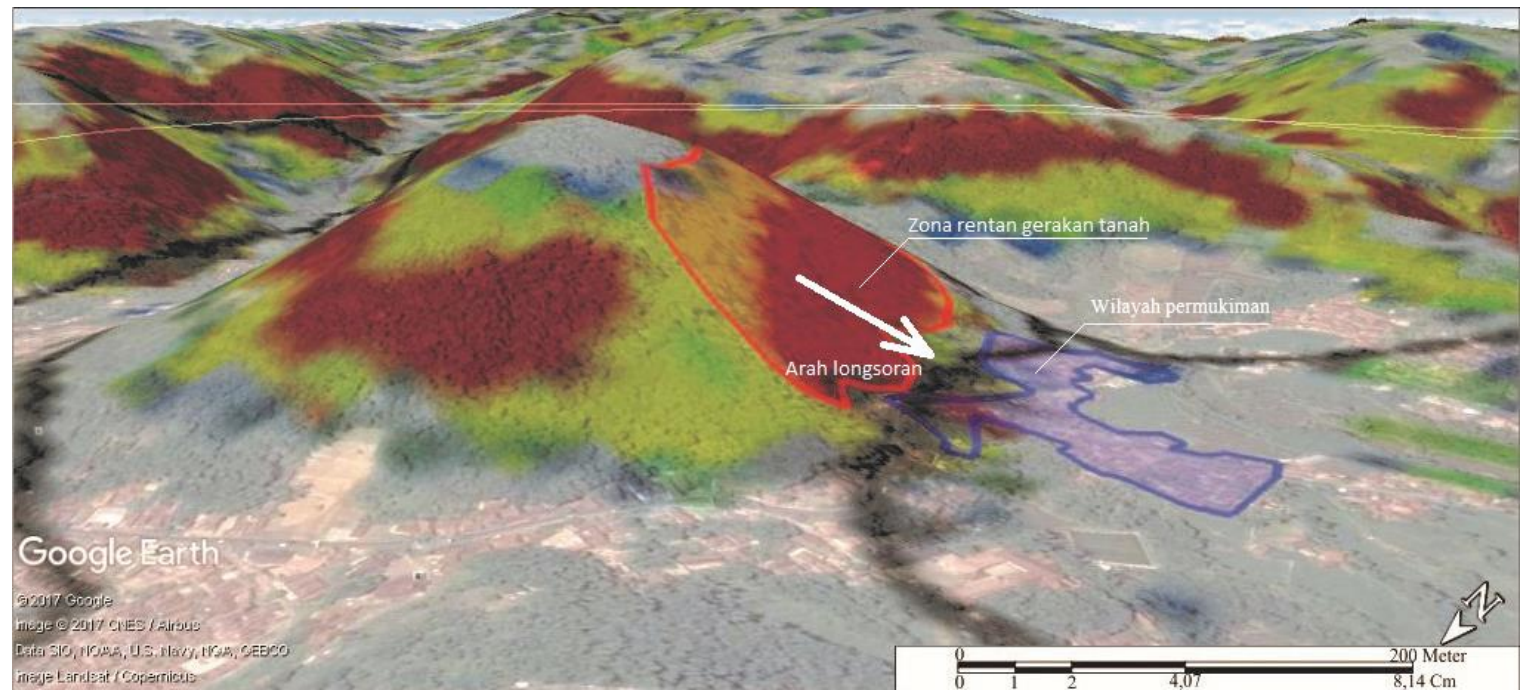

Gambar 8. Lereng perbukitan pada zona kerentanan gerakan tanah tinggi hingga sangat tinggi di Desa Batulayang.

wilayah permukiman dengan menumpangtindihkan peta zonasi kerentanan gerakan tanah dengan petarupa bumi. Berikut adalah beberapa contoh hasil kajian potensi risiko bencana gerakan tanah pada beberapa daerah yang berada di zona kerentanan tinggi hingga sangat tinggi.

\section{Lokasi Desa Batulayang}

Gambar 8 menyajikan zonasi kerentanan gerakan tanah di lokasi Desa Batulayang. Lokasi gerakan tanah pada koordinat $770932 \mathrm{mE} / 9230271 \mathrm{mS}$, yang berada di punggung bukit dengan kemiringan lereng terjal. Berdasarkan morfologi lereng, jenis gerakan tanah yang dapat terjadi adalah jenis luncuran material tanah (earth slide), karena pergerakan sejajar dengan permukaan lerengnya yang terjal, dan materialnya berupa tanah atau campuran tanah dan batuan (berdasarkan Cruden dan Varnes, 1996).

Wilayah gerakan tanah berada di zona sangat tinggi yang nilai faktor keamanan $<1,0$ dan zona tinggi yang memiliki nilai FK berkisar antara 1,0 dan 1,2. Kondisi tutup lahannya terdiri dari 


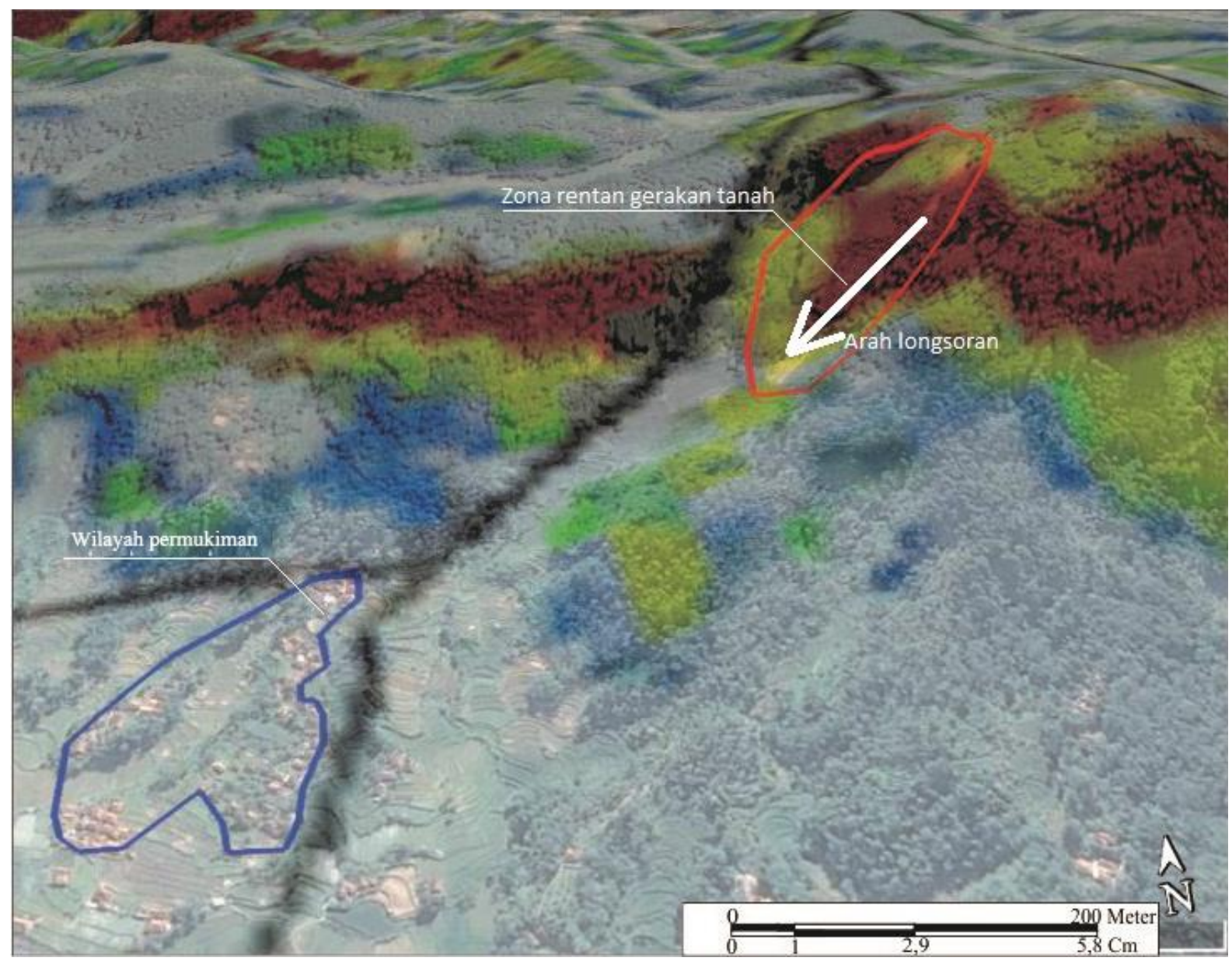

Gambar 9. Lereng perbukitan pada zona kerentanan gerakan tanah tinggi hingga sangat tinggi di Desa Mukapayung.

pepohonan yang lebat sehingga akan membuat lapisan tanah menjadi semakin kuat karena air hujan menjadi terserap oleh pepohonan dan tanah tidak cepat jenuh. Namun dari pengamatan citra Google Earth terdapat bentuk lahan yang tidak beraturan yang kemungkinan mengindikasikan adanya gerakan tanah lama yang pernah terjadi. Dengan demikian, meskipun tutupan lahan di daerah perbukitan ini didominasi oleh pepohonan, daerah perbukitan dapat menjadi zona kerentanan gerakan tanah sangat tinggi terutama pada kondisi curah hujan lebat, dimana pepohonan tidak akan mampu untuk mencegah infiltrasi air hujan ke dalam lereng. Daerah kerentanan gerakan tanah ini mempunyai perkiraan luas sekitar 7,4 hektar, yang merupakan gerakan tanah yang besar, dengan pergerakan ke arah barat menuju wilayah permukiman yang berada di kaki lereng. Wilayah permukiman tersebut dihuni oleh 38 kepala keluarga, hal ini menjadi risiko bencana bagi wilayah tersebut.

\section{Lokasi Desa Mukapayung}

Lokasi potensi gerakan tanah terletak dikoordinat $773246 \mathrm{mE} / 9227786 \mathrm{mS}$ yang berada di punggung bukit dengan kemiringan lereng terjal (Gambar 9). Wilayah gerakan tanah berada di zona kondisi tutup lahannya berupa lahan terbuka, sehingga dapat menyebabkan tanah lebih mudah menjadi jenuh ketika hujan turun. Jenis gerakan tanah diprediksi termasuk jenis aliran tanah (earth flow) atau aliran rombakan (debris flow), karena bergerak mengalir menuruni lereng pada daerah aliran air dan materialnya berupa tanah dan atau bercampur dengan batuan (berdasarkan Cruden dan Varnes, 1996).

Daerah potensi gerakan tanah mempunyai perkiraan luas sekitar 3,33 hektar. Pergerakan tanah ini mengarah ke baratdaya menuju wilayah permukiman yang berada di kaki lereng perbukitan, sehingga dapat menimbulkan potensi risiko bencana di wilayah permukiman tersebut 
dengan jumlah warga yang diperkirakan berisiko sebanyak 27 kepala keluarga.

\section{KESIMPULAN}

Berdasarkan hasil pemodelan kerentanan gerakan tanah di wilayah Kecamatan Cililin dengan menggunakan aplikasi TRIGRS, diperoleh kesimpulan bahwa faktor-faktor utama yang mengontrol tingkat kerentanan gerakan tanah di lokasi penelitian adalah kemiringan lereng dan karakteristik keteknikan tanah. Kerentanan gerakan tanah tinggi hingga sangat tinggi cenderung terjadi pada daerah perbukitan dengan kemiringan lereng lebih dari $16^{\circ}$ dan pada lapisan tanah yang terbentuk dari pelapukan formasi Beser.

Pengaruh curah hujan terhadap kerentanan gerakan tanah sangat signifikan pada daerah kerentanan gerakan tanah sangat tinggi. Akan tetapi, kenaikan intensitas hujan saja tidak dapat memberi pengaruh yang besar terhadap perubahan kerentanan gerakan tanah. Hasil pemodelan mengindikasikan bahwa durasi curah hujan menjadi faktor utama yang menyebabkan ketidakstabilan lereng pada zona kerentanan menengah.

Pada daerah lereng dengan kerentanan sangat tinggi, jenis gerakan tanah yang dapat terjadi berupa luncuran tanah atau aliran bahan rombakan karena dikontrol oleh kemiringan lereng yang terjal. Hasil pemodelan perubahan zona kerentanan gerakan tanah akibat pengaruh curah hujan dapat digunakan untuk mengkaji potensi ancaman dan risiko gerakan tanah di wilayah pemukiman di Kecamatan Cililin.

\section{UCAPAN TERIMA KASIH}

Penulis mengucapkan terima kasih kepada Kepala Pusat Penelitian Geoteknologi LIPI yang telah memberikan izin untuk melakukan penelitian ini. Demikian pula kami mengucapkan terima kasih kepada para teknisi laboratorium Geologi Teknik, Pusat Penelitian Geoteknologi LIPI yang telah membantu dalam pengujian mekanika tanah.

\section{DAFTAR PUSTAKA}

Baum, R. L ., Savage, W. Z., dan Dodt, J. W., 2002. TRIGRS-A Fortran program for transient rainfall infiltration and grid-based regional slope-stability analysis. U.S.
Geological Survey Open-File Report 020424, 27 pp.

BNPB, 2018. Data Informasi Bencana Indonesia (DIBI), http://dibi/bnpd.go.id/DesInventar/ simple_data.jsp. Diunduh pada tanggal 10 Mei 2018.

Chen, C. Y., Chen, T. C., Yu, F. C., dan Lin, S. C., 2005. Analysis of time-varying rainfall infiltration induced landslide, Engineering Geology, 48, 466-479.

Cruden, D. M., Varnes, D. J., 1996, Landslide types and processes,Special Report, Transportation Research Board, National Academyof Sciences, 247, 36-75.

Dietrich, W. E., Wilson, C. J., Montgomery, D. R., dan McKean, J., 1993. Analysis of erosion thresholds, channel networks and landscape morphology using a digital terrain model, Journal of Geology, 101, 259-178.

Dietrich, W. E., Reiss, R., Hsu, M. L., dan Montgomery, D. R.,1995. A Process-based model for colluvium soil depth and shallow landsliding using digital elevation data, Hydrological Process, 9, 383-400.

Godt, J. W., Baum, R. B., Savage, W. Z., Salciarini, D., Schulz, W. H., dan Harp, E. L., 2008. Transient deterministic shallow landslide modelling: Requirements for susceptibility and hazard assessments in a GIS framework, Engineering Geology, 102, 214-226.

Iverson, R. M., 2000. Landslide triggering by rain infiltration. Water Resources Research, 36, 1897-1910.

Kim, D., Im, S., Lee, S. H., Hong, Y., dan Cha, K. S., 2010. Predicting the rainfall-triggered landslides in a forested mountain region using TRIGRS model, Journal of Mountain. Sciences, 7(1), 83-91.

Koesmono, M., Kusnama, Suwarna, N., 1996. Peta Geologi lembar Sindangbarang dan Bandarwaru Jawa Barat Skala 1:100.000. Direktorat Geologi, Bandung.

Montgomery, D. R., dan Dietrich, W. E., 1994. A physically based model for the topographic control on shallow landsliding, Water Resources Research, 30, 1153-1171. 
Montgomery, D. R., Sullivan, K., dan Greenberg, H. M., 1998. Regional test of a model for shallow landsliding, Hydrological Process, 12, 943-955.

Pack, R. T., Tarboton, D. G., dan Goodwin, C. N.: Terrain stability mapping with SINMAP, Technical description and users guide for version 1.00, Report and software available at http://www. engineering.usu.edu/dtarb/ (last access: 15 June 2007), 1998.

Pack, R. T., Tarboton, D. G., dan Goodwin, C. N., 2001. Assessing terrain stability in a GIS using SINMAP, inthe 15th annual GIS conference, GIS 2001, Vancouver, 56-68, 19-22 February 2001.

PVMBG (Pusat Vulkanologi dan Mitigasi Bencana Geologi), 2011. Peta kerentanan gerakan tanah Kabupaten Bandung Barat,Badan Geologi,Kementrian Energi dan Sumber Daya Mineral,.

Sarah, D., Sugianti, K., Lestiana, H., 2015. Regional slope stability assessment of Tawangmangu District, Central Java, Proceeding of International Conference on Landslide and Slope Stability, N3-1 - N35, Bali, Indonesia.

Salciarini, D., Godt, J. W., Savage, W. Z., Conversini, P., Baum, R. L., dan Michael, J. A., 2006. Modeling regional initiation of rainfall-induced shallow landslides in the eastern Umbria Region of central Italy, Landslides, 3, 181-194.

Silitonga, P. H., 1973. Peta Geologi lembar Bandung Skala 1;100.000. Direktorat Geologi, Bandung.

Sudjatmiko, 1972. Peta Geologi lembar Cianjur 1;100.000. Direktorat Geologi, Bandung.

Sugianti, K., Sukrisyanti, Tohari, A., 2016. Model kerentanan gerakan tanah wilayah Kabupaten Sukabumi secara spasial dan temporal. Jurnal Riset Geologi dan Pertambangan 26(2), 117 - 129.

Tohari, A., Sarah, D., Sumardi, E., T. 2005. Studi pengaruh curah hujan terhadap gerakan tanah di Sumedang, Jawa Barat. Laporan Penelitian Puslit Geoteknologi-LIPI: Bandung.
Ward, T. S., 1976. Factor safety approach to landslide potential delineation. Ph.D Dissertation. Department of Civil Engineering, Colarado State University, Fort Collins, Colorado.

Vieira, B. C., Fernandes, N. F., dan Filho, O. A., 2010. Shallow landslide prediction in the Serra do Mar, São Paulo, Brazil, Nat. Hazards Earth Syst. Sci., 10, 1829-1837, DOI : 10.5194/nhess-101829-2010. 